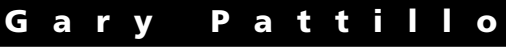

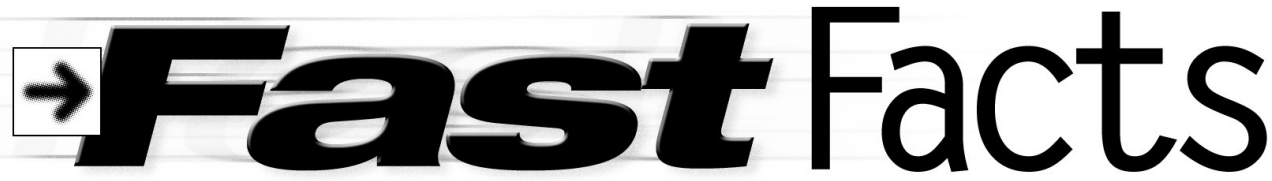

\section{International students}

The number of international students at colleges and universities in the United States increased by six percent to a record high of 764,495 in the 2011-12 academic year. U.S. students studying abroad increased by one percent. There are 31 percent more international students studying at U.S. colleges and universities than there were a decade ago. China, India, and South Korea are the top three places of origin. This year, international exchanges in all 50 states contributed $\$ 22.7$ billion to the U.S. economy.

Institute of International Education, "Open Doors 2012 Report on International Educational Exchange," November 13, 2012, www.iie.org/ /media/Files/Corporate/Open-Doors/Open-Doors-Briefing-November-2012.ashx (retrieved December 19, 2012)

\section{$\rightarrow$ Doctoral degrees}

A total of 163,765 doctoral degrees were conferred by degree-granting institutions in 2010-11, the latest date for which comprehensive data are available. There has been a steady increase in the number since the 1970-71 academic year in which 64,998 doctoral degrees were conferred. Health professions and related programs represented the largest number in 2010-11. Legal professions and studies represented the largest number in 1970-71. English language and literature showed the sharpest decline, from 1,554 to 1,344.

National Center for Education Statistics, "Digest of Education Statistics, Table 288. Doctor's Degrees Conferred by Degreegranting Institutions, by Field of Study: Selected Years, 1970-71 through 2010-11," 2012, http://nces.ed.gov/programs /digest/d12/tables/dt12_288.asp (retrieved January 7, 2013).

\section{$\rightarrow$ North American print holdings}

Of the 128.1 million distinct print book publications represented in WorldCat, 45.7 million are held by at least one institution located in either the United States or Canada. WorldCat contains more than 258 million records.

Brian Lavoie, Constance Malpas, and JD Shipengrover, "Print Management at 'Mega-scale': A Regional Perspective on Print Book Collections in North America," Dublin, Ohio: OCLC Research, 2012, www.oclc.org/research/publications /library/2012/2012-05.pdf (retrieved January 2, 2013).

\section{E-book vs. print}

"In the past year, the number of those who read e-books increased from 16 percent of all Americans ages 16 and older to 23 percent. At the same time, the number of those who read printed books in the previous 12 months fell from 72 percent of the population ages 16 and older to 67 percent. Overall, the number of book readers in late 2012 was 75 percent of the population ages 16 and older, a small and statistically insignificant decline from 78 percent in late 2011." Lee Rainie and Maeve Duggan, "E-book Reading Jumps; Print Book Reading Declines," December 27, 2012, http:// libraries.pewinternet.org/2012/12/27/e-book-reading-jumps-print-book-reading-declines (retrieved January 7, 2013).

\section{$\rightarrow$ Tweets at Library of Congress}

The Library of Congress (LOC) has acquired the public tweets from Twitter's archive. As of January 2013, LOC has an archive of approximately 170 billion tweets. The size of the files, including metadata, is 133.2 terabytes for two compressed copies. LOC could make available any portion of the collection six months after it was originally posted on Twitter to "bona fide" researchers. Library of Congress, "Update on the Twitter Archive at the Library of Congress," January, 2013, www.loc.gov/today/pr/2013 /files/twitter_report_2013jan.pdf (retrieved January 7, 2013).

Gary Pattillo is reference librarian at the University of North Carolina-Chapel Hill, e-mail: pattillo@email. unc.edu 